\title{
Hubungan komposisi tubuh dengan kesegaran jasmani pada atlet hockey
}

\author{
Nandita Nury Latifah, Ani Margawati, Ayu Rahadiyanti * \\ Departemen Ilmu Gizi, Fakultas Kedokteran, Universitas Diponegoro \\ Jalan Prof. Soedarto No.13, Tembalang, Kota Semarang, Jawa Tengah 50275, Indonesia. \\ * Corresponding Author. Email: ayurahadiyanti@fk.undip.ac.id \\ Received: 10 November 2019; Revised: 9 December 2019; Accepted: 12 December 2019
}

\begin{abstract}
Abstrak
Komposisi tubuh yang tidak optimal dapat menurunkan kesegaran jasmani atlet sehingga dapat terjadi penurunan performa ketika bertanding. Tujuan dari penelitian ini adalah mengetahui hubungan persen lemak tubuh, persen massa otot, dan somatotype dengan kesegaran jasmani pada atlet hockey. Desain penelitian yaitu cross-sectional dengan jumlah subjek 35 atlet di Pelatihan Hockey Universitas Negeri Semarang dan Universitas Negeri Yogyakarta yang dipilih dengan purposive sampling. Data persen lemak tubuh dan persen massa otot diukur menggunakan bioelectrical impedence analysis (BIA). Data somatotype menggunakan metode antropometri Heath-Carter dan data kesegaran jasmani berupa nilai VO2max diambil menggunakan metode Balke. Analisis data menggunakan uji Pearson, Rank Spearman dan uji regresi linier. Sebagian besar atlet hockey $(54,3 \%)$ memiliki nilai VO2max dengan kategori baik. Nilai persen lemak tubuh terendah 6,8\% dan nilai tertinggi $35 \%$. Nilai persentase massa otot terendah $23,9 \%$ dan nilai tertinggi $40,9 \%$. Nilai rata-rata dari nilai endomorph, mesomorph, dan ectomorph adalah $(-0,04) \pm 0,3 ; 4,2 \pm 0,9 ;$ dan $2,3 \pm 1,2$. Ada hubungan yang signifikan antara persen lemak tubuh $(\mathrm{p}<0,001)$, persen massa otot $(\mathrm{p}<0,001)$, nilai endomorph $(\mathrm{p}<0,001)$, dan nilai ectomorph $(\mathrm{p}=0,016)$ dengan nilai $\mathrm{VO} 2 \mathrm{max}$. Variabel yang paling berkaitan dengan nilai VO2max adalah persen lemak ( $\mathrm{p}<0,001)$.
\end{abstract}

Kata kunci: massa lemak, massa otot, somatotype, kesegaran jasmani, hockey

\section{Correlation of body composition with physical fitness of hockey athletes}

\begin{abstract}
Suboptimal body composition could reduce the physical fitness and performance of athletes. This study analyzed the relationship of percent body fat, percent muscle mass and somatotype on physical fitness in hockey athletes. This study was a cross-sectional study with 35 athletes in Pelatihan Hockey Universitas Negeri Semarang and Universitas Negeri Yogyakarta which selected by purposive sampling. Percent body fat and percent muscle mass were measured using bioelectrical impedance analysis (BIA). Somatotype measurement used the anthropometric Heath-Carter method and physical fitness (VO2max) measurement by the Balke method. Data were analyzed using the Pearson test, Rank-Spearman test, and Linear Regression test. Most hockey athletes (54.3\%) had good VO2max value. The lowest percentage of body fat was $6.8 \%$. The highest percentage of muscle mass was $40.9 \%$. The average value of the endomorph, mesomorph, and ectomorph values were $(-0.04) \pm 0.3 ; 4.2 \pm 0,9$; and $2.3 \pm 1.2$. There were a significant relationship between percent body fat ( $p<0.001$ ), percent muscle mass ( $p<0.001)$, endomorph value ( $p<0.001)$, and ectomorph value $(p=0.016)$ with VO2max value. Percent of body fat was the most related variable to VO2max $(p<0.001)$.
\end{abstract}

Keywords: fat mass, muscle mass, somatotype, physical fitness, hockey

How to Cite: Latifah, N., Margawati, A., \& Rahadiyanti, A. (2019). Hubungan komposisi tubuh dengan kesegaran jasmani pada atlet hockey. Jurnal Keolahragaan, 7(2). doi:https://doi.org/10.21831/jk.v7i2.28085

do: https://doi.org/10.21831/jk.v7i2.28085

\section{PENDAHULUAN}

Kunci dari pencapaian prestasi pada atlet terletak pada performa. Performa atlet dalam sebuah pertandingan dipengaruhi oleh beberapa faktor salah satunya adalah kesegaran jasmani. Kesegaran jasmani yang baik dibutuhkan pada semua cabang olahraga karena dengan kesegaran jasmani yang baik atlet dapat melakukan penyesuaian terhadap beban fisik yang diberikan tanpa menimbulkan kelelahan yang berlebihan (Muhajir, 2016). Salah satu komponen dari kesegaran jasmani adalah daya tahan aerobik. Sema- 
Jurnal Keolahragaan 7 (2), 2019 - 147

Nandita Nury Latifah, Ani Margawati, Ayu Rahadiyanti

kin tinggi daya tahan aerobik atlet maka tingkat kelelahan atlet akan menurun (Karakoç et al., 2012; Stanula et al., 2014; Zebrowska et al., 2012). Hal ini disebabkan adanya konsumsi oksigen yang tinggi akan meningkatkan persebaran oksigen ke seluruh tubuh sehingga proses metabolisme anaerob dapat diminimalisir dan tidak menghasilkan asam laktat yang berlebihan (Stanula et al., 2014).

Daya tahan aerobik bisa diukur dengan melihat volume konsumsi oksigen maksimal yang masuk ke dalam tubuh (VO2max) (Hanjabam \& Kailashiya, 2014). VO2max dapat diukur dengan banyak metode salah satunya adalah metode Balke. Metode Balke cocok digunakan untuk tes ketahanan aerobik pada atlet olahraga permainan beregu dibandingkan olahraga individu (Herdiles et al., 2017). Daya tahan aerobik atlet dapat dipengaruhi secara signifikan oleh persen lemak tubuh, massa otot, dan somatotype (Esco et al., 2018; Marangoz \& Var, 2018).

Persen lemak tubuh dapat mempengaruhi kekuatan, kelincahan, dan performa atlet (Fink \& Mikesky, 2015). Jaringan lemak adalah jaringan inaktif sehingga dalam aktivitas fisik jaringan otot harus mengangkatnya secara berulang kali untuk melawan gravitasi (Gligoroska et al., 2015). Beberapa penelitian yang dilakukan pada atlet sepak bola dan handball menyimpulkan bahwa semakin tinggi persen lemak tubuh atlet maka kadar VO2max akan semakin rendah (Esco et al., 2018; Gligoroska et al., 2015; Marangoz \& Var, 2018). Selain itu, massa otot juga berpengaruh pada performa atlet, semakin tinggi massa otot yang dimiliki maka akan semakin kuat performa atlet. Jaringan otot adalah jaringan yang dapat menggerakkan rangka tubuh dan terdiri dari sel yang dapat menghasilkan energi. Semakin banyak jaringan otot dalam tubuh maka semakin tinggi kebutuhan oksigen untuk menghasilkan energi. Peningkatan energi yang dihasilkan akan meningkatkan daya tahan atlet sehingga massa otot berhubungan positif secara signifikan dengan VO2max (Esco et al., 2018; Gligoroska et al., 2015; Vaara et al., 2012).

Selain persen lemak tubuh dan persen massa otot, penelitian juga menunjukkan adanya hubungan yang signifikan antara somatotype dengan kesegaran jasmani pada atlet sepak bola dan handball (Anggitasari et al., 2019; Marangoz $\&$ Var, 2018). Tipe somatotype yang cocok pada atlet dengan olahraga intensitas tinggi seperti basket, handball, dan hockey adalah mesomorphic (Gjonbalaj et al., 2018; Mathur et al., 1985).
Hal ini disebabkan olahraga intensitas tinggi dapat menurunkan jaringan lemak yang menumpuk dan meningkatkan pembentukan jaringan otot (Tomabechi et al., 2018). Selain itu, atlet yang memiliki tipe tubuh mesomorphic akan memiliki lebih banyak massa otot dibandingkan dengan massa lemak yang dapat mengurangi beban tubuh akibat adanya massa lemak dan meningkatkan energi yang dihasilkan oleh jaringan otot (Gligoroska et al., 2015; Marangoz \& Var, 2018; Vaara et al., 2012). Metode yang digunakan untuk mengukur somatotype adalah metode antropometri dan merupakan metode yang paling sering digunakan karena peralatan yang digunakan lebih sedikit dan perhitungan yang digunakan lebih sederhana (Anggitasari et al., 2019).

Salah satu olahraga yang sedang dikembangkan Indonesia adalah hockey, namun belum banyak penelitian yang dilakukan pada atlet hockey di Indonesia. Hockey merupakan salah satu cabang permainan olahraga dengan intensitas tinggi yang dimainkan secara beregu. Setiap pemain menggunakan alat yang disebut stik untuk menahan, menggiring, dan memukul bola sesuai dengan peraturan permainan yang telah ditetapkan (Basri, 2013). Permainan hockey membutuhkan kesegaran jasmani yang baik, seperti daya tahan aerobik, kekuatan otot, kecepatan, kelenturan, kelincahan, ketangkasan, keseimbangan, dan koordinasi (Fink \& Mikesky, 2015). Namun beberapa penelitian menunjukkan nilai kesegaran jasmani pada atlet hockey lebih rendah dibanding olahraga intensitas tinggi lainnya. Penelitian yang dilakukan menunjukkan bahwa hockey memiliki nilai VO2max paling rendah dibandingkan dengan atlet olahraga basket, handball, sepak bola, dan voli dengan rata-rata nilai $\mathrm{VO} 2 \mathrm{max}$ atlet hockey sebesar 33 $\mathrm{ml} / \mathrm{kg} / \mathrm{min}$ (Adeloye et al., 2016). Hasil yang sama juga ditunjukkan pada penelitian yang dilakukan pada atlet handball dan hockey dengan rata-rata nilai $\mathrm{VO} 2 \mathrm{max}$ atlet hockey sebesar $42,37 \mathrm{ml} / \mathrm{kg} / \mathrm{min}$ (Mir \& Bari, 2017). Padahal nilai VO2max atlet hockey seharusnya berkisar $60 \mathrm{ml} / \mathrm{kg} / \mathrm{min}$ (Moroščák et al., 2013). Hasil skrining yang sebelumnya telah dilakukan menunjukkan atlet hockey Jawa Tengah memiliki nilai rata-rata $\mathrm{VO} 2 \mathrm{max} 49,1 \mathrm{ml} / \mathrm{kg} / \mathrm{min}$ pada lakilaki dan $43,6 \mathrm{ml} / \mathrm{kg} / \mathrm{min}$ pada perempuan. Selain itu, beberapa penelitian juga menunjukkan bahwa persen lemak tubuh pemain hockey lebih tinggi dibandingkan pemain handball, basket, dan voli (Garrido-Chamorro et al., 2012).

Hockey berpotensi untuk menambah prestasi di masa sekarang karena olahraga hockey 
mulai banyak diminati oleh masyarakat. Terbukti dengan banyaknya kejuaraan yang mulai diikuti baik di tingkat nasional maupun internasional. Namun belum banyak prestasi yang dapat diraih oleh atlet Indonesia. Berdasarkan penelitian yang telah dipaparkan, penelitian terkait komposisi tubuh dan kesegaran jasmani masih terbatas pada atlet hockey. Nilai kesegaran jasmani pada sepak bola, handball, dan basket sangat berkaitan dengan persen lemak tubuh, persen massa otot, dan somatotype. Hal tersebut dapat meningkatkan performa atlet hockey dalam berkompetisi karena permainan hockey membutuhkan kesegaran jasmani yang baik, seperti daya tahan aerobik, kekuatan otot, kecepatan, kelenturan, kelincahan, ketangkasan, keseimbangan, dan koordinasi. Oleh karena itu peneliti ingin mengetahui hubungan persen lemak tubuh, massa otot, dan somatotype dengan kesegaran jasmani pada atlet hockey.

\section{METODE}

Penelitian ini dilakukan di Pelatihan Hockey Universitas Negeri Semarang dan Universitas Negeri Yogyakarta pada bulan Agustus 2019. Penelitian ini merupakan penelitian observasional dan termasuk dalam ruang lingkup ilmu gizi masyarakat. Perhitungan besar sampel menggunakan rumus estimasi proporsi. Subjek penelitian ini adalah 35 atlet yang dipilih menggunakan metode purposive sampling, dengan kriteria inklusi, yakni berusia 19-25 tahun, rutin mengikuti latihan untuk kompetisi, tidak sedang cedera atau dalam perawatan dokter dan bersedia menjadi subjek penelitian.

Variabel bebas dalam penelitian ini adalah persen lemak tubuh, persen massa otot, dan nilai somatotype. Variabel terikat dalam penelitian ini adalah kesegaran jasmani berupa nilai VO2max. Variabel perancu dalam penelitian ini adalah asupan zat gizi, kebiasaan merokok, dan aktivitas fisik berupa latihan maupun non-latihan. Variabel perancu akan diuji hubungannya dengan VO2max untuk melihat tergolong variabel perancu atau bukan. Data yang dikumpulkan berupa data karakteristik subjek, persen lemak tubuh, persen massa otot, nilai somatotype, nilai VO2max, asupan zat gizi, kebiasaan merokok, durasi latihan, dan aktivitas fisik non-latihan.

Data karakteristik subjek berupa usia dan jenis kelamin diambil dengan kuesioner data diri. Data persen lemak tubuh dan persen massa otot subjek diukur menggunakan alat hand to foot Bioelectrical Impedance Analysis (BIA) seri BHF-375, kategori persen lemak tubuh untuk laki-laki athletic (5-10\%), good (11-14\%), acceptable (15-20\%), overweight (21-24\%), dan obese (>24\%) dan untuk perempuan athletic (8$15 \%)$, good (16-23\%), acceptable (24-30\%), overweight (31-36\%), dan obese (>36\%) (Jeukendrup \& Gleeson, 2010). Kategori persen massa otot pada laki-laki tinggi ( $>44 \%)$, normal (40-44\%), kurang $(<40 \%)$, sedangkan untuk perempuan tinggi (>33\%), normal (31-33\%), kurang (<31\%) (Janssen et al., 2000). Nilai somatotype diukur menggunakan metode antropometri Heath-Carter dengan mengukur berat badan, tinggi badan, lemak bawah kulit (Trisep, Supscapula, Calf, dan Supraspinal), lebar tulang (Humerus Width, Fumerus Width), dan lingkar tubuh (fixed arm girth, fixed calf girth) yang masing-masing diukur dua kali. Hasil dicatat dan dihitung untuk menentukan nilai somatotype (endomorph, mesomorph, dan ectomorph) menggunakan rumus Heath-Carter (Tóth et al., 2014). Nilai VO2max diambil dengan metode Balke dengan cara atlet harus lari selama 15 menit dan dicatat jarak yang ditempuh kemudian dihitung menggunakan rumus Balke (Fink \& Mikesky, 2015).

Terkait analisis variabel perancu, asupan zat gizi diambil dengan metode Recall 24-hour dalam 3 hari yang tidak berturut-turut dan kemudian dianalisis untuk mengetahui asupan zat gizi. Kebiasaan merokok diambil dari kuesioner kebiasaan merokok untuk mengetahui jumlah rokok yang dihabiskan dalam sehari. Aktivitas fisik latihan dilihat dari durasi latihan dalam satu minggu yang diambil dengan kuesioner. Nilai aktivitas fisik non-latihan diambil dengan International Physical Activity Quesionaire (IPAQ) (Hagströmer et al., 2006).

Data dianalisis dengan uji korelasi Pearson dan uji Rank Spearman. Analisis dilakukan untuk melihat hubungan persen lemak tubuh, persen massa otot, nilai somatotype, dan variabel perancu dengan VO2max. Analisis multivariat yang digunakan adalah uji regresi linier untuk mengetahui variabel yang paling berkaitan pada kesegaran jasmani (Dahlan, 2011). Seluruh pelaksanaan penelitian ini telah memperoleh persetujuan dari Komite Etik Penelitian Kesehatan (KEPK) Fakultas Kedokteran Universitas Diponegoro/Rumah Sakit Umum Pusat dr. Kariadi No.397/EC/KEPK/FK UNDIP/IX/2019.

\section{HASIL DAN PEMBAHASAN}

Tabel 1 menunjukkan bahwa penelitian ini didominasi oleh atlet laki-laki sebanyak 54,3\%. Perbedaan tingkat kesegaran jasmani dipicu oleh 
banyak faktor, seperti faktor genetik, kadar hemoglobin, jenis kelamin, usia, asupan zat gizi, komposisi tubuh, konsumsi rokok, konsumsi alkohol, dan aktivitas fisik (Fink \& Mikesky, 2015). Usia rata-rata dari atlet adalah $21 \pm 1,7$ tahun yang masuk dalam rentang usia optimal dalam pencapaian nilai VO2max (Loe et al., 2013) Tempat tinggal atlet dibagi menjadi dua yaitu asrama dan tidak asrama. Sebagian besar atlet bertempat tinggal di asrama (54,3\%). Tempat tinggal berpengaruh pada frekuensi dan durasi latihan. Studi menyatakan bahwa frekuensi dan durasi latihan yang lebih tinggi akan meningkatkan kesegaran jasmani (Penggalih et al., 2017) walaupun dalam penelitian ini tidak menunjukkan hasil yang sama. Rata-rata IMT subjek adalah $21,9 \pm 2,5 \mathrm{~kg} / \mathrm{m}^{2}$ dengan persentase terbanyak $(74,3 \%)$ tergolong status gizi normal. Rata-rata persen lemak tubuh subjek adalah 18,8 $\pm 7,8 \%$ dengan persentase terbanyak berada dalam kategori good sebesar 42,9\%. Rata-rata persen massa otot subjek adalah $31,17 \pm 4,96 \%$ dengan kategori paling dominan adalah kurang yaitu sebesar 94,2\%. Kategori somatotype yang paling dominan dari atlet hockey adalah endomorph-mesomorph, yaitu sebanyak $68,9 \%$. Ratarata VO2max subjek adalah 44,1 $\pm 4,58$ dengan kategori paling dominan adalah baik 54,3\% .

Tabel 2 menunjukkan bahwa aktivitas fisik dibagi menjadi dua yaitu aktivitas fisik latihan dan aktivitas fisik non-latihan. Nilai aktivitas fisik non-latihan pada atlet memiliki rentang yang cukup jauh dengan nilai minimal sebesar 633 METs-menit/minggu dan nilai maksimal sebesar 4764 METs-menit/minggu. Hal ini disebabkan adanya perbedaan tempat tinggal dan aktivitas di luar latihan yang dilakukan oleh atlet. Atlet yang tinggal di asrama memiliki durasi latihan yang lebih lama (4-6 jam) dibandingkan dengan yang tidak asrama (3-4 jam), namun memiliki aktivitas fisik yang lebih rendah dibandingkan yang tidak di asrama.

Tabel 1. Karakteristik Subjek

\begin{tabular}{|c|c|c|c|c|c|c|}
\hline Karakteristik & $\mathrm{n}$ & $\%$ & $\overline{\mathrm{X}} \pm \mathrm{SD}$ & Med & Min & Maks \\
\hline \multicolumn{7}{|l|}{ Jenis kelamin } \\
\hline Laki-laki & 19 & 54,3 & & & & \\
\hline Perempuan & 16 & 45,7 & & & & \\
\hline \multicolumn{7}{|l|}{ Tempat tinggal } \\
\hline Asrama & 19 & 54,3 & & & & \\
\hline Tidak asrama & 16 & 45,7 & & & & \\
\hline Usia (tahun) & & & $21 \pm 1,7$ & & 19 & 25 \\
\hline IMT $\left(\mathrm{kg} / \mathrm{m}^{2}\right)$ & & & $21,9 \pm 2,5$ & 21,5 & 16,6 & 29,4 \\
\hline \multicolumn{7}{|l|}{ Status Gizi (Fukuda et al., 2017) } \\
\hline Kurus & 1 & 2,9 & & & & \\
\hline Normal & 26 & 74,3 & & & & \\
\hline Gemuk & 6 & 17,1 & & & & \\
\hline Obesitas & 2 & 5,7 & & & & \\
\hline Lemak tubuh (\%) (Jeukendrup et al., 2010) & & & $18,8 \pm 7,8$ & 19,5 & 6,8 & 35 \\
\hline Athletic & 7 & 20 & & & & \\
\hline Good & 15 & 42,9 & & & & \\
\hline Acceptable & 10 & 28,6 & & & & \\
\hline Overweight & 3 & 8,6 & & & & \\
\hline Massa otot (\%) (Janssen et al., 2000) & & & $31,17 \pm 4,96$ & 34,8 & 23,9 & 40,9 \\
\hline Tinggi & 1 & 2,9 & & & & \\
\hline Normal & 1 & 2,9 & & & & \\
\hline Kurang & 33 & 94,2 & & & & \\
\hline \multicolumn{7}{|l|}{ Tipe Somatotype } \\
\hline Central & 1 & 2,9 & & & & \\
\hline Endomorphic mesomorph & 1 & 2,9 & & & & \\
\hline Endomorph-mesomorph & 24 & 68,9 & & & & \\
\hline Balance mesomorph & 1 & 2,9 & & & & \\
\hline Mesomorphic endomorph & 8 & 22,9 & & & & \\
\hline VO2max (ml/kg/menit) (Heyward et al., 2014) & & & $44,1 \pm 4,58$ & 44,1 & 33,7 & 52,3 \\
\hline Kurang & 1 & 2,9 & & & & \\
\hline Sedang & 10 & 28,6 & & & & \\
\hline Baik & 19 & 54,3 & & & & \\
\hline Sangat baik & 5 & 14,3 & & & & \\
\hline
\end{tabular}


Jurnal Keolahragaan 7 (2), 2019 - 150

Nandita Nury Latifah, Ani Margawati, Ayu Rahadiyanti

Tabel 2. Karakteristik dan Hubungan Variabel Perancu dengan VO2max

\begin{tabular}{lccccc}
\hline \multicolumn{1}{c}{ Karakteristik } & $\overline{\mathrm{X}} \pm \mathrm{SD}$ & Med & Min & Maks & Nilai $\mathrm{p}$ \\
\hline Durasi latihan (jam/minggu) & $17,4 \pm 5,7$ & 20 & 9 & 24 & $0,109^{* *}$ \\
Nilai aktivitas fisik (METs-menit/minggu) & $2450 \pm 1381$ & 2337 & 633 & 4764 & $0,923^{*}$ \\
Jumlah batang rokok (batang/hr) & $1,31 \pm 2,9$ & 0 & 0 & 12 & $0,010^{*}$ \\
Asupan energi (kkal/hr) & $1525 \pm 378$ & 1510 & 800 & 2394 & $0,135^{*}$ \\
Asupan karbohidrat (g/hr) & $202,6 \pm 49,9$ & 212,2 & 97 & 298,8 & $0,054^{*}$ \\
Asupan protein (g/hr) & $51,5 \pm 11,5$ & 50,2 & 26,2 & 73,7 & $0,722^{*}$ \\
Asupan lemak (g/hr) & $54,5 \pm 20,3$ & 51,1 & 20 & 98,9 & $0,801^{*}$ \\
Asupan vitamin B1(mg/hr) & $0,4 \pm 0,1$ & 0,5 & 0,2 & 0,6 & $0,484^{* *}$ \\
Asupan vitamin B2 (mg/hr) & $0,8 \pm 0,4$ & 0,7 & 0,4 & 2,4 & $0,439^{*}$ \\
Asupan zat besi (mg/hr) & $7,5 \pm 3,3$ & 194,6 & 3 & 20,7 & $0,143^{*}$ \\
Asupan magnesium (mg/hr) & $202 \pm 74,5$ & 7 & 83,4 & 426,2 & $0,175^{*}$ \\
\hline
\end{tabular}

* uji Pearson,

** uji Rank-Spearman

Berdasarkan Tabel 2 rata-rata asupan energi dari atlet hockey adalah $1525 \mathrm{kkal} / \mathrm{hari}$ padahal kebutuhan energi dari atlet tersebut adalah sekitar 2300-3450 kkal/hari. Asupan energi (dari sumber karbohidrat, lemak, dan protein) yang kurang dapat disebabkan banyak faktor salah satunya kurangnya pengetahuan atlet mengenai kebutuhan gizi pada atlet. Kurangnya asupan energi dapat memicu kurangnya simpanan glikogen dalam otot sehingga atlet cepat mengalami kelelahan. Tidak hanya itu, atlet juga dapat mengalami hipoglikemia pada saat melakukan pertandingan atau latihan (Fink \& Mikesky, 2015).

Atlet hockey yang merokok berjumlah 7 orang dengan rata-rata 6-7 batang rokok perhari. Dari semua variabel perancu yang diuji hubungan dengan VO2max hanya jumlah batang rokok yang dihisap yang memiliki hubungan yang signifikan dengan nilai VO2max. Merokok memiliki hubungan korelasi negatif yang signifikan $(\mathrm{p}=0,010 ; \mathrm{r}=-0,429)$ dengan nilai VO2max. Hasil ini sejalan dengan penelitian sebelumnya (Anggraeni \& Wirjatmadi, 2019). Kandungan karbonmonoksida dalam asap rokok dapat berikatan dengan hemoglobin 200-300 kali lebih kuat dibandingkan dengan oksigen. Hal ini dapat mengganggu pengangkutan oksigen ke jaringan yang dibutuhkan untuk proses metabolisme energi aerobik (Gani, 2002). Tabel 2 menunjukkan bahwa variabel zat gizi (energi, karbohidrat, protein, lemak, vitamin B1, vitamin B2, besi, magnesium) dan aktivitas fisik berupa latihan maupun non-latihan bukan merupakan variabel perancu dalam penelitian ini.

Tabel 3 menunjukkan hubungan persen lemak tubuh dengan nilai VO2max memiliki nilai korelasi negatif yang kuat sebesar -0,736 yang berarti semakin tinggi nilai persen lemak tubuh, maka akan menurunkan nilai VO2max. Hubungan persen massa otot dengan nilai $\mathrm{VO} 2 \mathrm{max}$ memiliki nilai korelasi positif sebesar 0,592 yang

berarti semakin tinggi nilai persen massa otot, maka akan meningkatkan nilai VO2max. Hubungan nilai endomorph dengan nilai $\mathrm{VO} 2 \mathrm{max}$ memiliki nilai korelasi negatif yang kuat sebesar $-0,716$ yang berarti semakin tinggi nilai endomorph, maka akan menurunkan nilai $\mathrm{VO} 2 \mathrm{max}$. Hubungan nilai ectomorph dengan nilai VO2max memiliki nilai korelasi positif sebesar 0,404 yang berarti semakin tinggi nilai ectomorph, maka akan meningkatkan nilai VO2max.

Tabel 3. Hubungan Persen Lemak Tubuh, Persen Massa Otot, dan Nilai Somatotype dengan $\mathrm{VO} 2 \mathrm{max}$

\begin{tabular}{lcc}
\hline \multicolumn{1}{c}{ Variabel } & $\mathrm{r}$ & $\mathrm{P}$ \\
\hline Persen lemak tubuh & $-0,736$ & $<0,001^{*}$ \\
Persen massa otot & 0,592 & $<0,001^{* *}$ \\
Endomorph & $-0,716$ & $<0,001^{* *}$ \\
Mesomorph & $-0,140$ & $0,422^{*}$ \\
Ectomorph & 0,404 & $0,016^{*}$ \\
\hline
\end{tabular}

* uji Pearson

** uji Rank-Spearman

Rata-rata persen massa otot atlet hockey adalah $31,17 \%$ dengan kategori paling dominan adalah kurang, padahal persen massa otot pada atlet seharusnya lebih dari 44\% (Janssen et al., 2000). Persen massa otot memiliki hubungan yang signifikan $(\mathrm{p}<0,001)$ dengan nilai $\mathrm{VO} 2 \mathrm{max}$ pada atlet hockey. Hasil penelitian dengan uji Rank-Spearman menunjukkan adanya korelasi positif $(\mathrm{r}=0,592)$ antara persen massa otot dan nilai VO2max, yang artinya semakin tinggi persentase massa otot maka akan meningkatkan nilai VO2max. Hasil ini sesuai dengan penelitian yang dilakukan pada mahasiswa di India yang menunjukkan adanya korelasi positif antara persen massa otot dengan nilai VO2max (Saha, 2015).

Semakin banyak jaringan otot dalam tubuh maka semakin tingi kebutuhan oksigen untuk menghasilkan energi. Peningkatan kebutuhan 
energi ini akan memacu peningkatan daya tahan atlet. Otot yang terlibat dalam aktivitas fisik secara teratur dan terus menerus maka sistem sirkulasi dan respiratori akan meningkatkan sistem kerjanya untuk penyediaan oksigen dalam pembentukan energi pada kerja otot. Semakin banyak oksigen yang masuk dalam tubuh, maka sistem metabolisme aerobik akan meningkat dan memperlambat terjadinya kelelahan pada atlet (Fink \& Mikesky, 2015).

Jaringan otot terdiri dari sel-sel yang aktif dan dapat menyimpan glikogen. Ketika atlet melakukan olahraga maka simpanan glikogen akan digunakan untuk pembentukan energi. Waktu yang dibutuhkan pada proses pembentukan energi dari glikogen lebih sedikit dari pada waktu yang digunakan untuk mengubah lemak menjadi energi (Baar, 2010). Semakin banyak jumlah jaringan otot maka semakin banyak juga glikogen yang dapat disimpan sehingga semakin banyak pula energi yang dapat dihasilkan. Massa otot dapat ditingkatkan dengan meningkatkan asupan protein dan karbohidrat serta latihan fisik yang optimal (Baar, 2010).

Hasil menunjukkan bahwa kategori somatotype yang paling dominan adalah endomorphmesomorph, artinya nilai endomorph dan mesomorph sebanding dan nilai ectomorph lebih kecil dari keduanya. Hasil ini tidak sesuai dengan penelitian yang dilakukan di Nigeria yang menunjukkan kategori somatotype yang ideal adalah endomorphic mesomorph, yang artinya nilai mesomorph yang paling dominan dan nilai endomorph lebih tinggi dibandingkan nilai ectomorph (Toriola et al., 1985). Hasil dari penelitian ini menunjukkan bahwa terdapat hubungan negatif kuat pada nilai endomorph $(\mathrm{p}<0,001)$ dan hubungan positif pada nilai ectomorph $(\mathrm{p}=0,016)$ dengan nilai VO2max (Tabel 3). Penelitian lain menunjukkan hasil yang sama, seperti penelitian yang dilakukan pada atlet handball dengan korelasi negatif pada nilai endomorph $(\mathrm{r}=-0,702)$ dan korelasi positif pada nilai ectomorph $(\mathrm{r}=0,609)$. Tipe tubuh endomorph memiliki kadar lemak yang lebih banyak dibanding dengan tipe tubuh yang lain maka dari itu semakin tinggi nilai endomorph akan menurunkan nilai VO2max (Marangoz \& Var, 2018). Penelitian juga menunjukkan bahwa ada hubungan positif yang signifykan antara nilai endomorph dan persen lemak tubuh serta hubungan negatif yang signifikan antara nilai endomorph dengan persen massa otot. Sebaliknya, tipe tubuh ectomorph memiliki kadar lemak tubuh dan massa otot yang lebih sedikit dibanding dengan tipe tubuh yang lain,
(Tóth et al., 2014) sehingga pada atlet hockey akan menguntungkan karena pergerakkan atlet tersebut menjadi lebih gesit (Fink \& Mikesky, 2015). Penelitian ini juga menunjukkan adanya hubungan yang negatif antara nilai ectomorph dengan persen lemak tubuh serta hubungan yang positif antara nilai ectomorph dan persen massa otot (Tabel 4).

Tabel 4. Hubungan Persen Lemak Tubuh dan Persen Massa Otot dengan Nilai Somatotype

\begin{tabular}{lcccc}
\hline \multirow{2}{*}{ Variabel } & \multicolumn{4}{c}{ Persen lemak tubuh Persen massa otot } \\
\cline { 2 - 5 } & $\mathrm{r}$ & $\mathrm{p}$ & $\mathrm{r}$ & $\mathrm{p}$ \\
\hline Endomorph & 0,874 & $<0,001^{* *}$ & $-0,827$ & $<0,001^{* *}$ \\
Mesomorph & 0,218 & $0,207^{*}$ & $-0,151$ & $0,358^{* *}$ \\
Ectomorph & $-0,605$ & $<0,001^{*}$ & 0,532 & $0,001^{* *}$ \\
\hline
\end{tabular}

* uji Pearson

** uji Rank-Spearman

Hasil dari penelitian ini menunjukkan bahwa tidak ada hubungan yang signifikan antara nilai mesomorph dengan nilai $\mathrm{VO} 2 \mathrm{max}$. Hasil ini tidak sesuai dengan penelitian yang dilakukan pada tentara Kroasia yang menunjukkan bahwa terdapat hubungan positif yang signifikan antara nilai mesomorph dengan nilai VO2max yang disebabkan mesomorph memiliki kaitan dengan kadar massa otot sehingga semakin tinggi kadar massa otot di dalam tubuh maka akan meningkatkan nilai VO2max (Sporis et al., 2011). Penelitian yang dilakukan pada mahasiswa di India juga menunjukkan hasil yang berlawanan, yaitu adanya hubungan positif yang signifikan antara nilai VO2max dengan nilai mesomorph (Saha, 2015). Terdapat penelitian yang menunjukkan hasil yang sama dengan penelitian ini, penelitian yang dilakukan pada atlet sepak bola di Macedonia menunjukkan hasil yang tidak signifikan antara nilai mesomorph dan nilai VO2max (Saiti et al., 2014). Penelitian ini juga tidak menunjukkan adanya hubungan yang signifikan antara nilai mesomorph dengan persen lemak tubuh dan persen massa otot. Hal ini disebabkan nilai mesomorph tidak hanya dipengaruhi oleh kadar massa otot dalam tubuh saja, namun juga dipengaruhi oleh massa tulang (Saitoglu et al., 2007)

Beberapa variabel yang memiliki nilai $\mathrm{p}<$ 0,25 dimasukkan dalam analisis multivariat seperti persen lemak tubuh, persen massa otot, nilai endomorph, nilai ectomorph, durasi latihan, jumlah batang rokok yang dihisap, asupan energi, asupan karbohidrat, asupan zat besi, dan asupan magnesium. Tabel 5 menunjukkan persamaan yang didapatkan dari hasil uji regresi linier tersebut untuk memprediksi tingkat kesegaran jasmani adalah $\mathrm{y}=52,168-0,432 \mathrm{x}$ (persen lemak 
Jurnal Keolahragaan 7 (2), 2019 - 152

Nandita Nury Latifah, Ani Margawati, Ayu Rahadiyanti

tubuh) dengan signifikansi $\mathrm{p}<0,001$, artinya setiap kenaikan persen lemak tubuh sebesar $1 \%$ akan terjadi penurunan kesegaran jasmani atlet hockey sebesar 0,432 $\mathrm{ml} / \mathrm{kg} / \mathrm{menit}$.

Tabel 5. Hasil Analisis Multivariat Regresi Linier

\begin{tabular}{cccc}
\hline Variabel & Konstanta & B & $\mathrm{p}$ \\
\hline Persen lemak tubuh & 52,168 & $-0,432$ & $<0,001$ \\
\hline
\end{tabular}

Hasil penelitian menunjukkan rata-rata persen lemak tubuh subyek adalah 18,8\% yang didominasi oleh kategori good, namun jika dibandingkan dengan persen lemak tubuh pada atlet, persen lemak tubuh subyek masih berlebih. menyatakan ada hubungan persen lemak tubuh dengan nilai VO2max $(\mathrm{p}<0,001)$ dan merupakan faktor yang paling berkaitan dengan VO2max. Berdasarkan nilai $\mathrm{R}^{2}$ sebesar 0,528 dapat diartikan bahwa sebesar 52,8\% tingkat kesegaran jasmani dipengaruhi oleh persen lemak tubuh dan $47,2 \%$ sisanya dipengaruhi variabel lain seperti persen massa otot, nilai endomorph, ectomorph, durasi latihan, asupan magnesium, asupan zat besi, asupan energi, dan asupan karbohidrat. Hal ini sesuai dengan penelitian yang dilakukan di Turki pada atlet handball yang memiliki kesimpulan bahwa terdapat korelasi negatif antara nilai VO2max dengan persen lemak tubuh $(\mathrm{p}<0,01)$ (Marangoz \& Var, 2018). Penelitian lain yang dilakukan pada atlet sepak bola di Republic of Macedonia menunjukkan hasil yang sama yaitu terdapat hubungan negatif antara nilai $\mathrm{VO} 2 \mathrm{max}$ dengan persen lemak tubuh (Gligoroska et al., 2015). Hasil yang sama juga ditunjukkan pada penelitian yang dilakukan di Amerika Serikat pada atlet sepak bola, semakin tinggi persentase lemak tubuh maka nilai VO2max akan semakin menurun (Esco et al., 2018).

Massa lemak tubuh yang berlebihan dapat membebani atlet dalam beraktivitas. Jaringan lemak merupakan jaringan inaktif yang harus diangkat secara berulang kali pada saat beraktivitas (Gligoroska et al., 2015). Seseorang yang overfat maka akan lebih banyak menggunakan energi untuk melakukan suatu pekerjaan dibandingkan dengan seseorang yang memiliki lemak tubuh normal atau kurang karena orang yang kelebihan lemak tubuh akan membutuhkan lebih banyak usaha untuk menggerakkan badan sehingga menyebabkan lelah lebih cepat (Garrow, 2005). Seseorang yang memiliki persen lemak tubuh lebih tinggi akan menurunkan curah jantung sehingga dapat menurunkan pompa darah ke seluruh tubuh, seorang atlet hal ini akan berdampak pada penurunan nilai VO2max karena konsumsi oksigen oleh jaringan akan menurun (Arum \& Mulyati, 2014). Konsumsi oksigen yang menurun pada saat latihan akan menyebabkan metabolisme energi anaerobik yang menghasilkan hasil samping asam laktat, apabila asam laktat menumpuk dapat mempercepat kelelahan otot pada atlet (Fink \& Mikesky, 2015).

\section{SIMPULAN}

Terdapat hubungan yang signifikan antara persen lemak tubuh $(\mathrm{p}<0,001)$, persen massa otot $(\mathrm{p}<0,001)$, nilai endomorph $(\mathrm{p}<0,001)$, nilai ecto$\operatorname{morph}(\mathrm{p}=0,016)$, dan konsumsi rokok dengan nilai VO2max. Variabel yang paling mempengaruhi nilai $\mathrm{VO} 2 \mathrm{max}$ adalah persen lemak tubuh $(\mathrm{p}<0,001)$. Persen lemak tubuh yang disarankan untuk atlet hockey adalah 8-15\% untuk laki-laki dan 12-18\% untuk perempuan. Persen massa otot yang disarankan untuk atlet adalah $>44 \%$ untuk laki-laki dan $>33 \%$ untuk perempuan. Bentuk tubuh yang disarankan adalah endomorphic mesomorph.

\section{DAFTAR PUSTAKA}

Adeloye, E. O., Ajayi-Vincent, O. B., \& Gbolabo, A. A. (2016). Cardiorespiratory endurance norm for university female athletes in southwestern Nigeria. Journal of Emerging Trends in Educational Research and Policy Studies, 7(3), 226233.

https://hdl.handle.net/10520/EJC196812

Anggitasari, E. D., Dieny, F. F., \& Candra, A. (2019). Hubungan somatotype dengan kesegaran jasmani atlet sepak bola. Jurnal Keolahragaan, 7(1), 11-22. https://doi.org/10.21831/jk.v7i1.21188

Anggraeni, L., \& Wirjatmadi, R. B. (2019). Status hemoglobin, kebiasaan merokok dan daya tahan kardiorespirasi (VO2 max) pada atlet unit kegiatan mahasiswa bola basket. Media Gizi Indonesia, 14(1), 27. https://doi.org/10.20473/mgi.v14i1.27-34

Arum, V. M., \& Mulyati, T. (2014). Hubungan intensitas latihan, persen lemak tubuh, dan kadar hemoglobin dengan ketahanan kardiorespirasi atlet sepak bola. Journal of Nutrition College, 3(1), 179-183. https://doi.org/10.14710/jnc.v3i1.4556

Baar, K. (2010). Train low-compete high! In A. Jeukendrup (Ed.), Sports Nutrition (pp. 79). Meyer \& Meyer Sport. http://www.cis.edu.rs/wpcontent/uploads/2014/09/Train-Low- 
Jurnal Keolahragaan 7 (2), 2019 - 153

Nandita Nury Latifah, Ani Margawati, Ayu Rahadiyanti

Compete-High.pdf

Basri, E. S. (2013). Perbandingan pengaruh metode bagian dengan metode keseluruhan terhadap penguasaan teknik push dalam cabang olahraga hoki. Universitas Pendidikan Indonesia.

Dahlan, M. S. (2011). Statistik untuk kedokteran dan kesehatan. Penerbit Salemba.

Esco, M., Fedewa, M., Cicone, Z., Sinelnikov, O., Sekulic, D., \& Holmes, C. (2018). Field-based performance tests are related to body fat percentage and fat-free mass, but not body mass index, in youth soccer players. Sports, 6(4), 105. https://doi.org/10.3390/sports6040105

Fink, H. H., \& Mikesky, A. E. (2015). Practical applications in sports nutrition (4 th). Jones and Bartlett Learning.

Fukuda, D. H., Hoffman, J. R., \& Stout, J. R. (2017). Strength and speed/power athletes. In H. C. Lukaski (Ed.), Body Composition Health and Performance in Exercise and Sport (pp. 211-231). CRC Press.

Gani, M. H. (2002). Ilmu kedokteran forensik. Fakultas Kedokteran Universitas Andalas.

Garrido-Chamorro, R., Sirvent-Belando, J. E., González-Lorenzo, M., Blasco-Lafarga, C., \& Roche, E. (2012). Skinfold sum: Reference values for top athletes. International Journal of Morphology, 30(3), http://www.intjmorphol.com/wpcontent/uploads/2015/08/art_05_303.pdf

Garrow, J. (2005). Body size and composition. In C. Geissler \& P. H. (Eds.), Human Nutrition (pp. 75-79). Elsevier.

Gjonbalaj, M., Georgiev, G., \& Bjelica, D. (2018). Differences in anthropometric characteristics, somatotype components, and functional abilities among young elite Kosovo soccer players based on team position. International Journal of Morphology, 36(1). http://www.intjmorphol.com/wpcontent/uploads/2018/02/art_07_361.pdf

Gligoroska, J. P., Manchevska, S., Efremova, L., Todorovska, L., \& Nikolic, S. (2015). Body composition and maximal oxygen consumption in adult soccer players in the Republic of Macedonia. Journal of Health Sciences, 5(3), 85-92. https://doi.org/10.17532/jhsci.2016.268

Hagströmer, M., Oja, P., \& Sjöström, M. (2006). The International Physical Activity Questionnaire (IPAQ): a study of concurrent and construct validity. Public Health Nutrition, 9(6), 755-762. https://doi.org/10.1079/PHN2005898

Hanjabam, B., \& Kailashiya, J. (2014). Effects of addition of sprint, strength and agility training on cardiovascular system in young male field hockey players: An echocardiography based study. IOSR Journal of Sports and Physical Education, l(4), 25-29.

Herdiles, H., Cholil, D. H., \& Komarudin, K. (2017). The difference of test results endurence using bleep test and balke test on football players Maung Bandung FC. IOP Conference Series: Materials Science and https://doi.org/10.1088/1757899X/180/1/012203

Heyward, V., \& Gibson, A. (2014). Advanced fitness assessment and exercise prescription (7th ed.). Human Kinetics.

Janssen, I. A. N., Heymsfield, S. B., Wang, Z. I. M., \& Ross, R. (2000). Skeletal muscle mass and distribution in 468 men and women aged $18-88 \mathrm{yr}$. Journal of Applied Physiology, 89(1), 81-88. https://doi.org/10.1152/jappl.2000.89.1.81

Jeukendrup, A., \& Gleeson, M. (2010). Sport nutrition: An introduction to energy and performance (2nd ed.). Human Kinetics.

Karakoç, B., Akalan, C., Alemdaroğlu, U., \& Arslan, E. (2012). The relationship between the Yo-Yo tests, anaerobic performance and aerobic performance in young soccer players. Journal of Human Kinetics, $35(1)$. https://doi.org/10.2478/v10078-012-0081$\mathrm{X}$

Loe, H., Rognmo, Ø., Saltin, B., \& Wisløff, U. (2013). Aerobic capacity reference data in 3816 healthy men and women $20-90$ years. PLoS ONE, 8(11). https://doi.org/10.1371/journal.pone.0064 319

Marangoz, I., \& Var, S. M. (2018). The relationship among somatotype structures, body compositions and estimated oxygen capacities of elite male handball players. Asian Journal of Education and Training, 4(3),

216-219. https://doi.org/10.20448/journal.522.2018 .43 .216 .219

Mathur, D. N., Toriola, A. L., \& Igbokwe, N. U. (1985). Somatotypes of Nigerian athletes of several sports. British Journal of Sports 
Jurnal Keolahragaan 7 (2), 2019 - 154

Nandita Nury Latifah, Ani Margawati, Ayu Rahadiyanti

Medicine, 19(4), 219-220. https://doi.org/10.1136/bjsm.19.4.219

Mir, B. A., \& Bari, M. A. (2017). A comparative study on cardiovascular endurance, explosive strength of legs and agility among female interuniversity handball \& hockey players. BRDU International Journal of Multidisciplinary Research, 2(2), 42-45. http://ijmdr.in/data/documents/FEBRUA RY_PAPER-5.PDF

Moroščák, J., Ružbarský, P., Balint, G., \& Vodicka, T. (2013). Anaerobic and aerobic fitness of ice hockey players throughout annual training cycle. Gymnasium: Scientific Journal of Education, Sports \& Health, $X I V(2)$. http://www.gymnasium.ub.ro/index.php/j ournal/article/view/280

Muhajir. (2016). Pendidikan jasmani, olahraga dan kesehatan untuk SMA/MA kelas X. Erlangga.

Penggalih, M. H. S., Juffrie, M., Sudargo, T., \& Sofro, Z. M. (2017). Correlation between nutritional status and lifestyle for youth soccer athlete performance: A cohort study. Pakistan Journal of Nutrition, 16(12), 895-905. https://doi.org/10.3923/pjn.2017.895.905

Saha, S. (2015). Somatic and body composition factors underlying aerobic capacity. American Journal of Sports Science, 3(2), 36-40. https://doi.org/10.11648/j.ajss.20150302.1 2

Saiti, B., Shukova-Stojmenovska, D., Zhivkoviq, V., Dalip, M., Ganiu, V., Telai, B., \& Ademi, A. (2014). Correlation between components of the somatotype and motor skills of young soccer participant in the first league in Republic of Macedonia. Proceedings (2014): Sport and Health, l(1), 18-25.

Saitoglu, M., Ardicoglu, O., Ozgocmen, S., Kamanli, A., \& Kaya, A. (2007). Osteoporosis risk factors and association with somatotypes in Males. Archives of Medical Research, 38(7), 746-751. https://doi.org/10.1016/j.arcmed.2007.03.
009

Sporis, G., Jukić, I., Bok, D., Vuleta, D., \& Harasin, D. (2011). Impact of body composition on performance in fitness tests among personnel of the Croatian navy. Collegium Antropologicum, 35(2), 335-339.

Stanula, A., Roczniok, R., Maszczyk, A., Pietraszewski, P., \& Zajac, A. (2014). The role of aerobic capacity in highintensity intermittent efforts in icehockey. Biology of Sport, 31(3). https://doi.org/10.5604/20831862.111143 7

Tomabechi, N., Takizawa, K., Shibata, K., \& Mizuno, M. (2018). Effects of 3-week work-matched high-intensity intermittent cycling training with different cadences on VO2max in University Athletes. Sports, 6(4). https://doi.org/10.3390/sports6040107

Toriola, A. L., Salokun, S. O., \& Mathur, D. N. (1985). Somatotype characteristics of male sprinters, basketball, soccer, and field hockey players. Journal of Sports Medicine, 6(6), 344-346. https://doi.org/10.1055/s-2008-1025868

Tóth, T., Michalíková, M., Bednarčíková, L., Živčák, J., \& Kneppo, P. (2014). Somatotypes in sport. Acta Mechanica et Automatica, 8(1), 27-32. https://doi.org/10.2478/ama-2014-0005

Vaara, J. P., Lainen, H. K., Niemi, J., Ohrankammen, O., Kkinen, A. H., Kocay, S., \& Hakkinen, K. (2012). Associations of maximal strength and muscular endurance test scores with cardiorespiratory fitness and body composition. Journal of Strength and Conditioning Research, 26(8), 20782086.

https://doi.org/10.1519/JSC.0b013e31823 b06ff

Zebrowska, A., Zyła, D., Kania, D., \& Langfort, J. (2012). Anaerobic and aerobic performance of elite female and male snowboarders. Journal of Human Kinetics, 34, 81-88. https://doi.org/10.2478/v10078-012-00669 